Article

\title{
A Feasibility Study on the Use of an Atmospheric Water Generator (AWG) for the Harvesting of Fresh Water in a Semi-Arid Region Affected by Mining Pollution
}

\author{
Julio A. Mendoza-Escamilla ${ }^{1}{ }^{(0}$, Francisco Josué Hernandez-Rangel ${ }^{1}{ }^{(1)}$, \\ Pedro Cruz-Alcántar 1,*(D), María Zenaida Saavedra-Leos ${ }^{1} \mathbb{D}$, Josefa Morales-Morales ${ }^{1} \mathbb{D}$, \\ Rafael A. Figueroa-Diaz ${ }^{2}$, César Manuel Valencia-Castillo ${ }^{3}$ (D) and Francisco J. Martinez-Lopez ${ }^{1}$ \\ 1 Department of Engineering, Autonomous University of San Luis Potosí, UASLP-COARA, 78700 Matehuala, \\ San Luis Potosí, Mexico \\ 2 Department of Electrical and Electronic Engineering, Sonora Institute of Technology, ITSON, \\ 85130 Cd Obregon, Mexico \\ 3 Department of Mechanical and Electrical Engineering, Autonomous University of San Luis Potosí, \\ UASLP-CARHS, 79960 Tamazunchale, San Luis Potosí, Mexico \\ * Correspondence: pedro.cruz@uaslp.mx
}

Received: 14 July 2019; Accepted: 6 August 2019; Published: 9 August 2019

\begin{abstract}
Worldwide, the shortage of fresh water has increased exponentially due to population growth and contamination of available water, especially in water tables that provide water for general consumption. One of the main pollutants of water is arsenic (As), present in the environment and in most mining/metallurgical processes, which is a major health risk, especially as a carcinogen. In the region of Matehuala, San Luis Potosi (SLP), Mexico, a highly productive mining area, arsenic concentrations of $138.1 \mathrm{mg} / \mathrm{kg}$ have been found in soils -6.2 times higher than what is allowed in domestic soils, while in water it is reported up to $158 \mathrm{mg} / \mathrm{L}$, exceeding permissible limits for human consumption. In addition to As pollution, the region suffers from water shortage both in the city and in rural communities. Therefore, it is necessary to explore new technologies to provide the population with fresh water. This paper presents a feasibility study on the use of an atmospheric water generator (AWG) to capture fresh water in the region of Matehuala, SLP. The region was found to have the necessary environmental conditions to use AWGs, with an annual average relative humidity (RH) of approximately $60 \%$. Using a mathematical model of a dehumidifier, water harvesting can be evaluated under the region's prevailing climatic conditions. The month with lowest harvest was found to be January, with 0.89 to $3.6 \mathrm{~L} /$ day, while the month with largest harvest was August at 3.9 to $18 \mathrm{~L} /$ day and water production costs of 0.0093 and $\$ 0.038 \mathrm{USD} / \mathrm{L}$, respectively. The study concludes that the use of AWGs would help alleviate water shortages, thus benefiting marginalized people or communities, preserving ecosystems and the environment.
\end{abstract}

Keywords: climatological analysis; freshwater harvesting; fresh water shortage; mining pollution; photovoltaic energy

\section{Introduction}

The lack of water suitable for human activities is a matter of global priority, since water is an element of survival for living beings. Despite the vast amount of water on the planet, most of it (97.5\%) is in seas with high salt content, rendering it unsuitable for human consumption, while the rest is found as fresh water $(2.5 \%)$. Of this fresh water, $70 \%$ is frozen and about $30 \%$ exists in the form of moisture or 
in underground aquifers [1,2]. Therefore, currently around 3.42 billion people experience acute fresh water shortage [3,4]. In addition to the above, part of the available fresh water suffers from serious pollution rates, especially of fluoride and arsenic (As). For its part, As is present in the atmosphere as an element that interacts with air, water and earth through dust present in air currents, and is even present in living organisms [5]. Some human activities, such as metallurgy in mining extraction processes, lead to the presence of As in the environment [6]. Such is the demand of As in mining processes that Mexico produces $7 \%$ of arsenic trioxide worldwide [7,8]. Arsenic toxicity is an environmental threat with health effects that include skin lesions, peripheral neuropathy, diabetes, cardiovascular diseases, damage to blood cells and cancer [9]. Human exposure to elevated levels of inorganic As occurs mainly through the ingestion of groundwater, foods prepared with this water, crops irrigated with water sources with high levels of As $[10,11]$, as well as through inhalation and the dermal route (contact with the contaminated soil) [12]. In Mexico, approximately $75 \%$ of the total population depend on groundwater for drinking, which is why some specifically arid and semi-arid regions have been diagnosed with HACRE (Chronic Endemic Regional Hydroarsenicism) and hydrofluorosis [13]. The state of San Luis Potosi, Mexico is recognised for its mining activity, specifically in Matehuala, SLP, a city whose main economic activities are mining and metallurgy, making it a high-risk area for population health, mainly that of children [14]. In Mexico, according to Official Mexican Standard NOM-147-SEMARNAT/SSA1 2004, safe concentration levels for residential users are $22 \mathrm{mg} / \mathrm{kg}$ in soils and $0.5 \mathrm{mg} / \mathrm{L}$ in drinking water for housing, livestock or agriculture $[15,16]$. Studies on mining pollution have been conducted in the Matehuala region for decades. A study [17] carried out to estimate the risk of human exposure to As during sports activities in a soccer club where contaminated water is used regularly for the irrigation of the land and pastures showed average arsenic concentrations in shallow soils of $138.1 \mathrm{mg} / \mathrm{kg}, 6.2$ times higher than that allowed in domestic soils $(22 \mathrm{mg} / \mathrm{kg}$ ). In addition, dermal contact of users exposed to contaminated soils resulted in a maximum carcinogenic risk value of $1.8 \times 10^{-5}$, an order of magnitude higher than the recommended risk value, while As concentrations in irrigation water were $6 \mathrm{mg} / \mathrm{L}$, higher than WHO (World Health Organization) permissible limits in drinking water, which explains soil contamination after irrigation. The mobility of As from metallurgical waste in Matehuala [18] has been classified as an ultra-high concentration $(4.8-158 \mathrm{mg} / \mathrm{L}$ ) in water used for recreational purposes, as well as for corn cultivation. Local corn crops showed a high bioaccumulation of As, up to 2.5 times of bioconcentration and $45 \%$ of translocation. The results of this study show that irrigation with water rich in As represents a significant risk for the population that consumes the contaminated crops [16]. Undoubtedly, arsenic is a major pollutant of aquifers and in the Matehuala region, where levels of up to $158 \mathrm{mg} / \mathrm{L}$ have been found in water for human consumption, exceeding the Mexican standard. Water for human consumption in the region is obtained from a set of 12 deep wells (recharge zones) located in communities outside the city of Matehuala and stored in 12 regulation tanks (discharge zones) located in the zone of study. Water quality in the recharge zones is considered adequate for domestic and agricultural use; however, storage and discharge areas register high As concentrations $[18,19]$ and large amounts of sodium hypochlorite, used in the disinfection of water collected in deep wells causing a chlorine odour and taste, which can cause health problems such as chest pain, vomiting, breathing difficulty, etc.

The above demonstrates the degree of the hydraulic distribution system contamination in the region coupled with soil contamination. In addition to water pollution in the region, other factors cause major water shortages, including limited precipitation coupled with population growth in the area. Annual rainfall in the region is $400 \mathrm{~mm}$ with annual evaporation that fluctuates between 1600 and $2000 \mathrm{~mm}$ [7]. The population in 2000 was 64,206 inhabitants with a volumetric water production of $6,274,629 \mathrm{~m}^{3}$; by 2017 the number of inhabitants had grown to 99,015 with a volumetric water production of $6,641,262 \mathrm{~m}^{3}$. Water service demand grew from 18,159 water intakes in 2000 to 28,776 in 2018. Inhabitants most affected by water shortage are rural communities and vulnerable sectors within the city [20]. Government strategy has focused on the exploration and creation of new deep wells affecting the groundwater table; for example, in 2014, approximately 262,000 USD were invested 
in drilling deep wells, of which $30 \%$ failed. Therefore, it is necessary to look for alternatives to supply freshwater without affecting the environment and with adequate conditions for human consumption or use in other activities. At a global level, various strategies have been presented to reduce water scarcity, specifically in the improvement of hydraulic distribution systems (storage, distribution, and irrigation systems), rainwater harvesting, seawater desalination technologies, water management, and atmospheric water harvesting [21-29]. From the latter, fog and dew are major sources of water for arid regions [30]. Dew is formed through two main steps: (1) Nucleation of a liquid phase forming a droplet on an obstacle, and (2) growth of the droplet at the expense of the surrounding atmosphere [31,32]. Based on the foregoing, various technologies have been developed for water harvesting, such as (i) salts or desiccants (liquids, solids and compounds) operating on various energy sources [33-36], (ii) smart materials such as bioinspired materials, nanostructured materials, gels and hydrogels [21,37,38], (iii) radiative cooling (Radiator-Condensers) by emitting thermal infrared radiation to the cold universe through the atmospheric window $[39,40]$ and (iv) direct cooling by commonly using conventional vapour compression (VC) refrigeration systems or other cooling technology $[2,41,42]$. This last method consists of cooling the air humidity mixture to a temperature below dew point, causing moisture condensation and water harvesting, which depend on atmospheric air, a huge and renewable water deposit. There are approximately 3100 cubic miles of water in the atmosphere, $98 \%$ of which are in the form of vapour, and $2 \%$ in the form of clouds. It is known that about 280 cubic miles of water evaporate or transpire daily into the atmosphere, and the amount of water in atmospheric air is about $14,000 \mathrm{~km}^{3}$ compared to only about $1200 \mathrm{~km}^{3}$ of fresh water on earth [41]. Devices that harvest water from the atmosphere are called atmospheric water generators (AWGs) and can be used successfully both in arid areas with low moisture content and in humid areas with high moisture content [22,42,43]. In this work, we present a feasibility study on the use of atmospheric water generators (AWGs) for harvesting atmospheric air water in the region of Matehuala, SLP. This area has high levels of As contamination from mining and metallurgical activities. The first stage of the work was to carry out a climatological study of the region to determine the environmental conditions and the possibilities of the use of renewable energies in AWGs; in the second stage, a basic dehumidifier model was developed to evaluate water capture in the region; finally, a feasibility analysis was conducted.

\section{Methodology}

The initial stage consisted of an analysis of the behaviour and predominant magnitudes of climatological variables such as temperature, humidity and radiation in the Matehuala region of SLP, Mexico. With this, a zone of opportunity can be established for the design and/or evaluation of atmospheric water generators (AWGs) within a psychrometric chart. In addition, a simple mathematical model was developed to analyse the energy process of a water dehumidifier that will be used as an AWG to obtain water from the environment under the predominant conditions of the study region.

\subsection{Study Area and Climatological Analysis}

Variables such as temperature, humidity, radiation and wind impact AWG use by controlling their capacity to capture water and the power source for operation. In this work, the climatological study is relevant for detecting the high, low and average temperature, humidity and radiation values in the study region in order to analyse the feasibility of using AWGs. The study was conducted in the municipality of Matehuala, San Luis Potosí, Mexico (Figure 1), which is located between $23^{\circ} 38^{\prime} 49^{\prime \prime}$ North and $100^{\circ} 38^{\prime} 37^{\prime \prime}$ West, with a land area of $1165.87 \mathrm{~km}^{2}, 223$ towns and approximately 99,015 inhabitants. Matehuala is at an average height of $1570 \mathrm{~m}$ above sea level, with calci-gypsiferous, clayey soil poor in organic matter $(0.2 \%)$. The city's main economic activities are mining and commerce. Climatological data were obtained from the meteorological station of the National Water Commission (CONAGUA), records were used from the network of automatic weather stations (EMAs) managed by the General Coordination of National Weather Service (CGSMN) with satellite transmission. These 
data were taken daily, every 10 min, over a period of 8 years spanning from 2010 to 2017 in Matehuala, San Luis Potosi, Mexico.

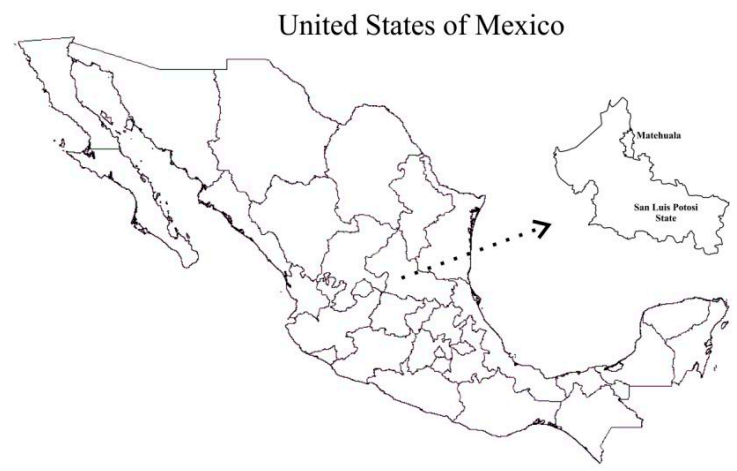

Figure 1. Map of México, which shows Matehuala, SLP.

Figure 2a shows temperature behaviour throughout the year, with an average high temperature of $22.88^{\circ} \mathrm{C}$ in June and an average low temperature of $13.14^{\circ} \mathrm{C}$ in January. Based on the results, the high temperature is most frequently registered after noon, while the low temperature occurs mostly in the early morning hours. Humidity behaves differently to temperature, decreasing from January to April and increasing until September. The minimum average humidity is $48.49 \%$ and the maximum average is $70.29 \%$ (Figure $2 b$ ). Figure $2 \mathrm{c}$ shows no significant relationship between temperature and relative humidity since, as mentioned above, the maximum amount of water vapour that air can contain depends on the temperature, though the amount of water is not guaranteed to be the same for each temperature point. Here it is observed that humidity does not follow the temperature pattern nor vice versa, since each is independent of the other.

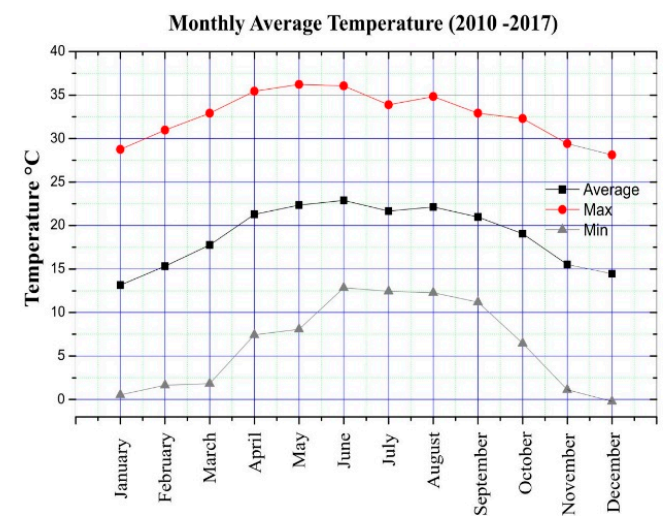

(a)

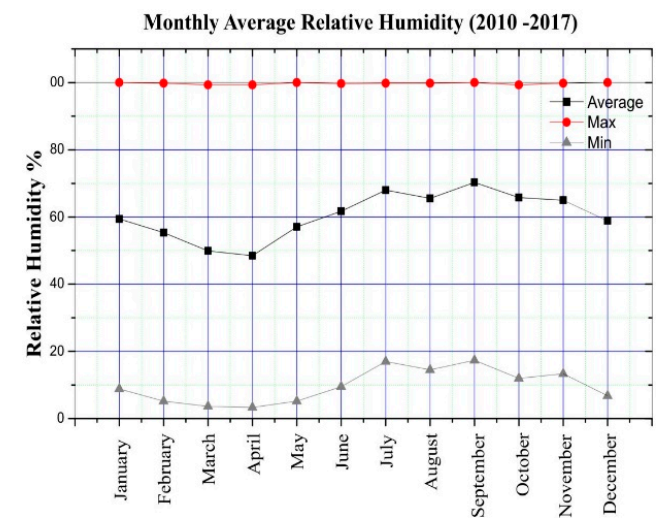

(b)

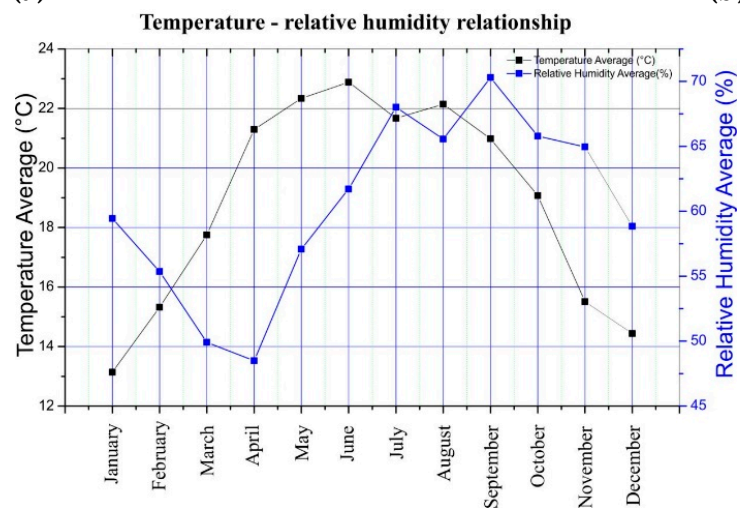

(c)

Figure 2. Statistical data of (a) temperature, $(\mathbf{b})$ relative humidity $(\mathrm{RH})$ and $(\mathbf{c})$ humidity and temperature ratio in Matehuala, SLP, Mexico (2010-2017). 
Temperature analysis corresponded with the area's type of climate whose temperature range is not extreme despite being located in a desert region. Moisture analysis results reveal that, despite being a desert area, the region has the potential and necessary resources for water extraction from the environment, using air humidity with a minimum average of $48.49 \%$ humidity as a source, sufficient for the operation of an AWG [42].

\subsubsection{Radiation and Wind Analysis}

The study showed that radiation and energy captured per square meter in the study region was considerable, with a maximum radiation value of $729.24 \mathrm{~W} / \mathrm{m}^{2}$ and a minimum value of $407.81 \mathrm{~W} / \mathrm{m}^{2}$ per day. The low general radiation mean was $150.04 \mathrm{~W} / \mathrm{m}^{2}$ and the high mean was $287.24 \mathrm{~W} / \mathrm{m}^{2}$ (Figure 3).

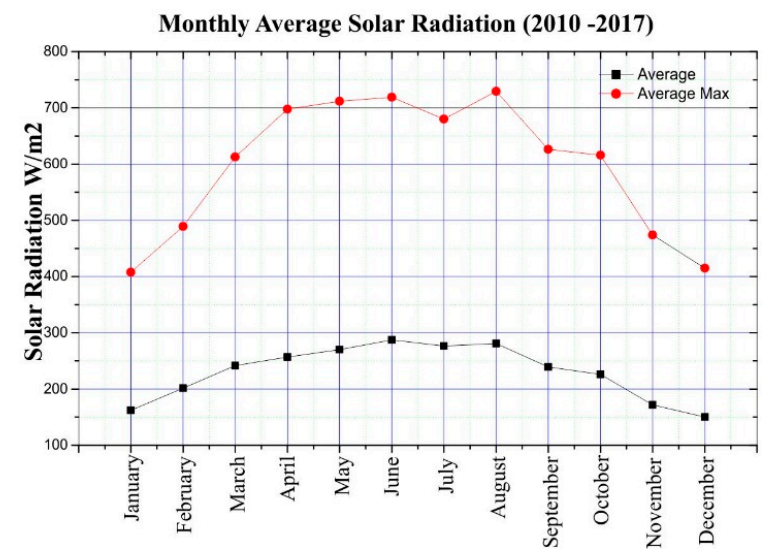

Figure 3. Statistical data of solar radiation in Matehuala SLP, Mexico (2010-2017).

Likewise, peak sun hours (PSH) for each month of the year were evaluated as shown below:

August shows 7.29 peak hours and January the lowest number of hours, at 4.08. There is a great potential of solar radiation energy that can be exploited as a possible source of energy for AWGs. With regard to wind energy, Figure 4 shows the variation of wind speed in the region throughout an average day for each month from 2010 to 2017.

\begin{tabular}{|l|l|}
\hline \multicolumn{1}{|c|}{ Month } & HPS \\
\hline January & 4.08 \\
\hline February & 4.89 \\
\hline March & 6.13 \\
\hline April & 6.98 \\
\hline May & 7.12 \\
\hline June & 7.19 \\
\hline July & 6.80 \\
\hline August & 7.29 \\
\hline September & 6.26 \\
\hline October & 6.16 \\
\hline November & 4.74 \\
\hline December & 4.15 \\
\hline
\end{tabular}

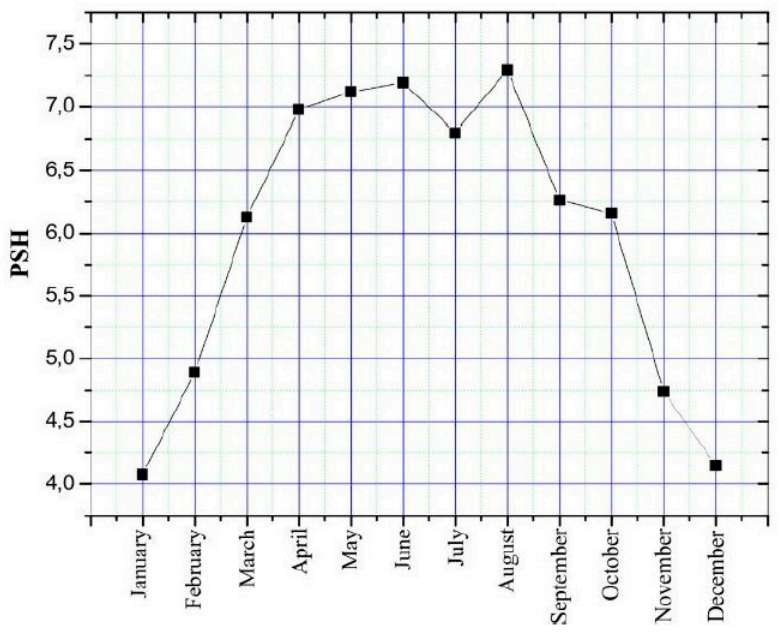

Figure 4. Average solar peak hours (PSH) for each month of the year (2010-2017). 
The results show top wind speeds of $6 \mathrm{~m} / \mathrm{s}$ for a Beaufort scale classification of "Strong Breeze". A minimum wind speed of $0 \mathrm{~m} / \mathrm{s}$, classified as "Calm", is also observed (Figure 5). In the early hours of the morning, winds range from 2.8 to $6.1 \mathrm{~m} / \mathrm{s}$, a "Gentle and Moderate Breeze" that fluctuates during the early hours of the morning. The wind speed tends to decrease, reaching soft winds, light winds and calm winds in an average of approximately $3 \mathrm{~h}$, after which time, the wind increases and its speed in the last remaining hours reaches a high of $6 \mathrm{~m} / \mathrm{s}$.

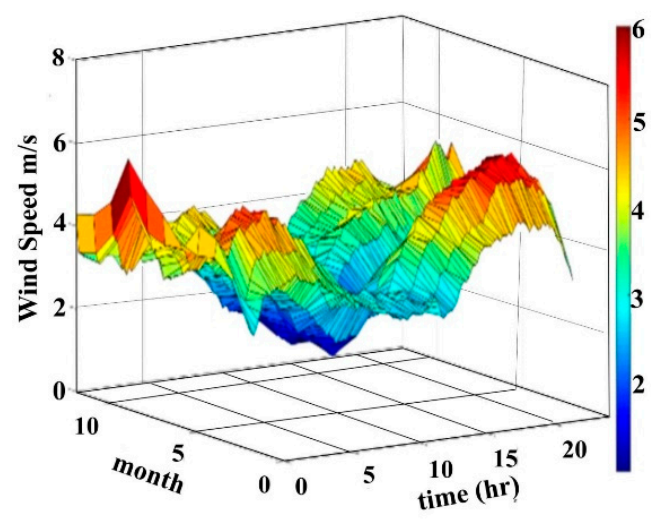

Figure 5. Wind speed ratio (m/s) (2010-2017).

Results showed that the highest wind speeds occur at night in spring and the end of summer with average speed ranging from 2.15 to $6.2 \mathrm{~m} / \mathrm{s}$. In addition, average speeds prevailing throughout the year were 2.15 to $4.2 \mathrm{~m} / \mathrm{s}$. These results suggest that the study area may be suitable for the generation of electrical or mechanical energy on a small scale, with several small turbines connected together to generate enough electric power.

Weather conditions for the city of Matehuala, SLP, are favourable for AWG use because its RH makes it a good source of water extraction. At the same time its high levels of solar radiation and wind can be used as an energy source for AWGs.

\subsubsection{Psychrometric Chart Characterisation in the Region}

The characterisation of the psychrometric zone of the study region was of great interest for this work since it provided information on the thermodynamic properties of humid air. The data of the variables of interest obtained in the statistical study were used to feed a simple model of a dehumidifier used as an AWG. With the dehumidifier model, the energy required to condense a specific amount of moisture contained in the atmospheric air could be estimated. In order to characterise the psychrometric zone of the study region, two input data were required-temperature, and high and low air humidity - which were located on the psychrometric chart to create the region's psychrometric zone. The values used were: low of $13.14^{\circ} \mathrm{C}$ and $48.49 \%$, high of $22.8^{\circ} \mathrm{C}$ and $70.29 \%$. The psychrometric zone can be seen in Figure 6 below. 


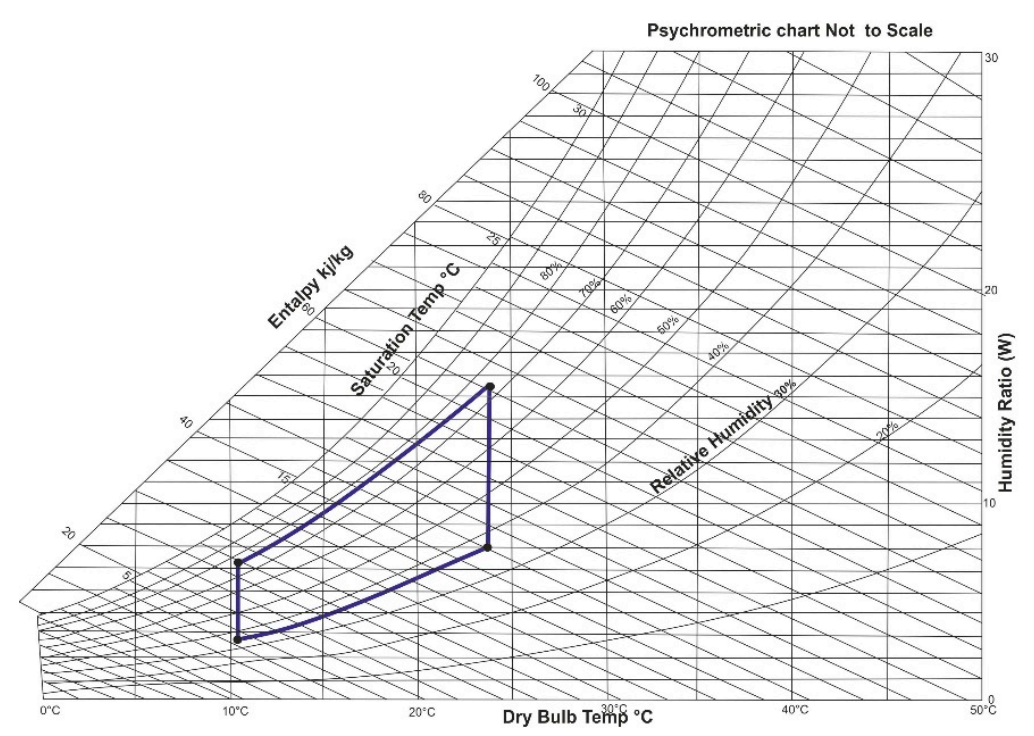

Figure 6. Psychrometric zone of opportunity for the use of atmospheric water generator (AWG) in Matehuala, SLP, Mexico.

According to the above figure, the region's psychrometric zone is favourable in terms of humidity and temperature since water vapour must be brought to dew point to extract air moisture. Proximity to the saturation curve can also be observed, indicating that there is not much road to be travelled to condense air humidity. This distance on the psychrometric chart is the amount of energy that has to be extracted from water vapour to be condensed.

\subsection{Mathematical Model of the Dehumidifier Used as AWG}

Moist air is a non-reactive mixture of dry air and water vapour. The mass ratio of water vapour and dry air is better known as specific humidity, varying depending on the area's features. In a given thermodynamic state, each of the components has certain properties that help determine the amount of energy required to condense water vapour. For a given system, during any continuous process in which there are interactions between dry air and water vapour, whether a humidifier, a dehumidifier or a dryer, humid air is supplied, and water can be extracted or added to that air and transfer heat, $Q$, from or to the system, for various purposes. The masses of water vapour $\left(m_{v}\right)$ and dry air $\left(m_{a}\right)$ are extensive properties that contributed to the mixture's total mass $\left(m_{t}\right)$, which are related as follows:

$$
m_{v}+m_{a}=m_{t}
$$

For the atmospheric water generator system, this mixture is the entry point, since energy calculations are made from it. For the process, the AWG system was considered an interaction process between dry air and water vapour represented by the physical model of Figure 7. 


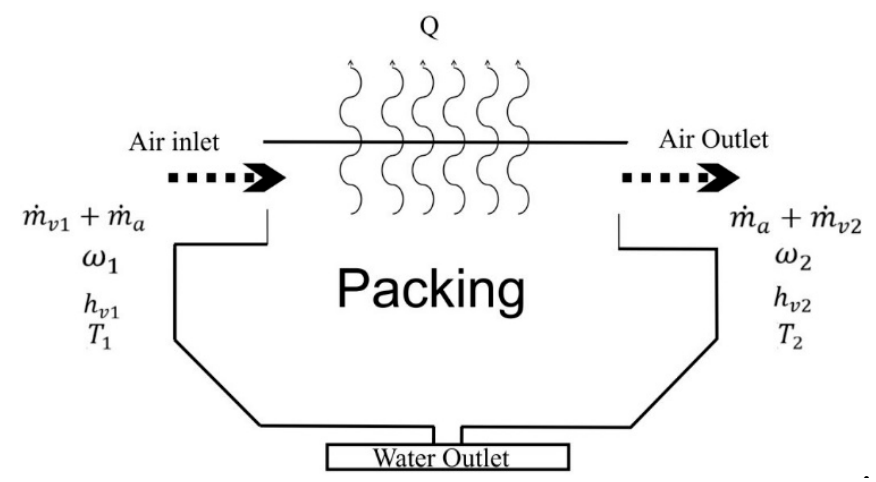

Figure 7. Schematic of physical model for the air dehumidification (AWG).

During the dehumidification process, mass and energy exchanges took place. Energy exchanges were estimated by considering the properties of the mixture under the system's inlet and outlet conditions. Inlet properties were determined by the system surroundings, while the outlet parameters were determined by the properties required for condensation and were proposed according to the percentage of water vapour reduction by condensation; in this case $25 \%, 50 \%$ and $75 \%$ reduction of water vapour. These percentages were selected so as not to affect the area's environmental surroundings or the ecosystems present in the region.

The following assumptions were made for the development of the model:

- $\quad$ The dry air entering the system changes only temperature in the process.

- Inlet specific humidity is necessarily greater than outlet specific humidity.

- Condensed water is in the sub-cooled state.

- Inlet and outlet enthalpy of water vapour depends on the amount of moisture contained in the water vapour.

- The proposed water vapour reduction is $25 \%, 50 \%$ and $75 \%$.

Thermodynamic Analysis

In order to balance mass and energy, the mixture properties must be known. In the climatological study carried out in this work, the psychrometric zone of the region was built. This zone has all the possible meteorological cases that can occur; therefore, this psychrometric zone was used to collect the data to be used in the model.

For the AWG process, the amount of moist air mass at the inlet is the mixture of dry air and water vapour that undergoes a condensation process until it leaves the system. Ideally, one would expect the water vapour in the incoming mixture to be completely condensed, but the reality is that it does not completely condense. The incoming dry air only undergoes a temperature change, being the means of transport for water vapour, and can be neglected. According to the conservation of mass, for the stationary process of condensation, component masses are related as follows:

$$
\begin{gathered}
\left(\dot{m}_{v 1}+\dot{m}_{a}\right)-\left(\dot{m}_{a}+\dot{m}_{v 2}\right)=\dot{m}_{3 l} \\
\dot{m_{v 1}}-\dot{m}_{v 2}=\dot{m}_{3 l}
\end{gathered}
$$

where

$\dot{m}_{v 1}=$ mass flow rate of water vapor entering, in $\mathrm{kg} / \mathrm{s}$

$\dot{m}_{a}=$ mass flow rate of dry air, in $\mathrm{kg} / \mathrm{s}$

$\dot{m}_{v 2}=$ mass flow rate of water vapor exiting, in $\mathrm{kg} / \mathrm{s}$

$\dot{m}_{3 l}=$ mass flow rate of condensed water, in $\mathrm{kg} / \mathrm{s}$ 
Specific humidity, $\omega$, is the ratio water vapour and dry air masses.

$$
\omega=\frac{m_{v}}{m_{a}}
$$

Specific humidity at input and output will then be:

$$
\begin{aligned}
& \omega_{1}=\frac{m_{v 1}}{m_{a}} \\
& \omega_{2}=\frac{m_{v 2}}{m_{a}}
\end{aligned}
$$

Using Equations (5) and (6) in Equation (3):

$$
\dot{m}_{a}\left(\omega_{1}-\omega_{2}\right)=\dot{m}_{3 l}
$$

Equation (7) is the mass balance in terms of specific humidity.

The specific enthalpy depends on the properties of the material, such as the temperature of the mixture at the input and output. The energy balance for the stationary system, disregarding kinetic and potential energy changes between input and output, and there being no work done on or from the system, is

$$
\left(\dot{m}_{a} h_{a 1}+\dot{m}_{v 1} h_{v 1}\right)+\dot{Q}=\left(\dot{m}_{a} h_{a 2}+\dot{m}_{v 2} h_{v 2}\right)+\dot{m}_{3 l} h_{3 l}
$$

where

$\dot{Q}=$ Heat transfer ratio to or from the system, in $\mathrm{J} / \mathrm{s}$

$h_{a 1}=$ Dry air inlet enthalpy, in $\mathrm{J} / \mathrm{kg}$

$h_{a 2}=$ Dry air outlet enthalpy, in $\mathrm{J} / \mathrm{kg}$.

$h_{v 1}=$ Water vapor inlet enthalpy, in $\mathrm{J} / \mathrm{kg}$.

$h_{v 2}=$ Water vapor outlet enthalpy, in $\mathrm{J} / \mathrm{kg}$

$h_{3 l}=$ Condensed water enthalpy, in $\mathrm{J} / \mathrm{kg}$

Dividing by the mass of dry air, the above equation, in terms of specific humidity, gives:

$$
\left(h_{a 1}+\omega_{1} h_{v 1}\right)-\frac{1}{\dot{m}_{a}} \dot{Q}=\left(h_{a 2}+\omega_{2} h_{v 2}\right)+\frac{\dot{m}_{3 l}}{\dot{m}_{a}} h_{3 l}
$$

Using Equation (7) in Equation (9) gives:

$$
\left(h_{a 1}+\omega_{1} h_{v 1}\right)-\frac{1}{\dot{m}_{a}} \dot{Q}=\left(h_{a 2}+\omega_{2} h_{v 2}\right)+\left(\omega_{1}-\omega_{2}\right) h_{3 l}
$$

Then, heat transfer for each unit of mass of dry air from the system to the surroundings gives:

$$
\frac{\dot{Q}}{\dot{m}_{a}}=\left(h_{a 1}+\omega_{1} h_{v 1}\right)-\left(h_{a 2}+\omega_{2} h_{v 2}\right)-\left(\omega_{1}-\omega_{2}\right) h_{3 l}
$$

With the above equation, heat transfer from the system to the surroundings that must be extracted for each unit of mass of dry air entering the system was determined. The heat transfer method used could be geothermal energy, solar energy, thermal energy from the sea, biomass energy, hybrid energy systems or by means of a refrigeration cycle, the latter being used for the case study presented herein $[42,44-51]$. 


\subsection{Case Study}

As mentioned above, there are several ways to transfer energy $(\mathrm{Q})$ to and from the AWG. For this study, a conventional vapour compression (VC) refrigeration system was proposed to extract the steam energy that enters the dehumidification process. Three packages of different cooling capacities were proposed: 1 ton of refrigeration, $\frac{1}{2}$ ton of refrigeration and $\frac{1}{4}$ ton of refrigeration in order to detect the capacities of humidity condensation and the amount of water harvested during a day in each month of the year. The cooling system was powered by a photovoltaic energy system consisting of several solar photovoltaic (PV) panels, with the intention of taking better advantage of the natural resources of the study area, such as solar radiation. Therefore, dimensioning of the photovoltaic systems for the proposed cooling capacities was carried out.

\section{Case Study Evaluation Process}

To solve the water dehumidifier model used as AWG, a computer program was developed that helps to obtain the value of the heat $(\mathrm{Q})$ necessary to extract for water harvesting. The process route is as follows:

1. Collection of climatological data (EMAS stations)

2. Statistical analysis of the variables of interest, such as temperature, humidity and solar radiation.

3. Delimitation of the psychrometric zone of opportunity for the Matehuala region belonging to the Altiplano Potosino region. The general data of the region's psychrometric zone were entered and vectors were created with increments of 0.2 with the entered data.

4. Collection of all thermodynamic properties for water vapour and dry air (enthalpies, dew point, specific volume, specific humidity, etc.) from the psychrometric zone.

5. Data obtained in Step 4 were entered into the mathematical model of the dehumidifier to obtain the amount of energy that must be extracted to the air-steam mixture to reduce its relative humidity by $25 \%, 50 \%$ and $75 \%$.

6. The case study was applied to $n$ refrigeration packages with the proposed refrigeration capacities.

7. Feasibility analysis was done with the results obtained.

\section{Results}

The amounts of heat extraction required to condense moisture for the three humidity reduction percentages $(25 \%, 50 \%$ and $75 \%)$ and for the percentages of relative air humidity $(50 \%, 60 \%$, and $70 \%)$ are shown in the following figure:

The Figure 8 shows the behaviour of heat to be extracted in order to condense the air humidity and the behaviour of each at the different amounts of relative humidity. For $25 \%, 50 \%$ and $75 \%$ of humidity reduction, emphasis is placed on the minimum and maximum values as can be seen in the following table. 


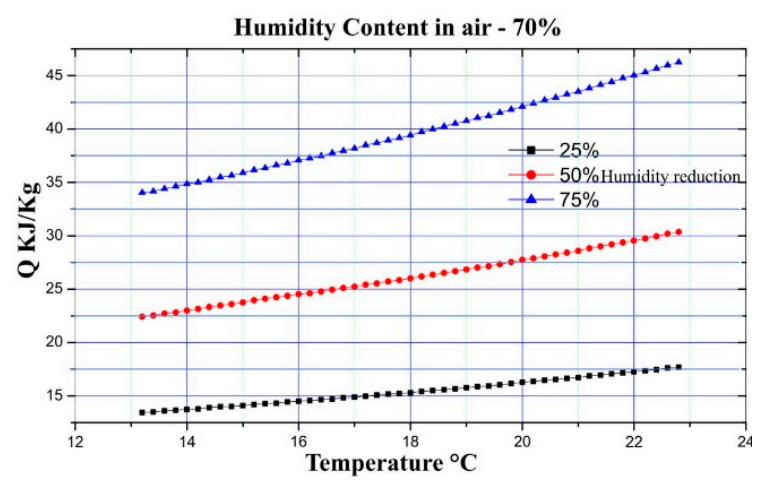

(a)

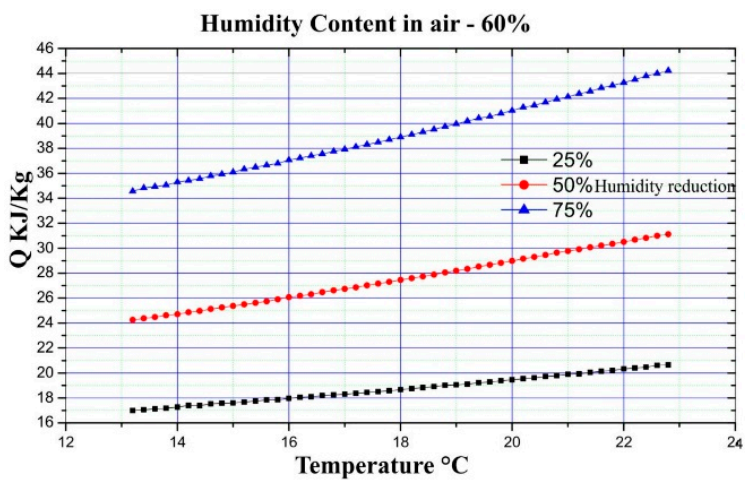

(b)

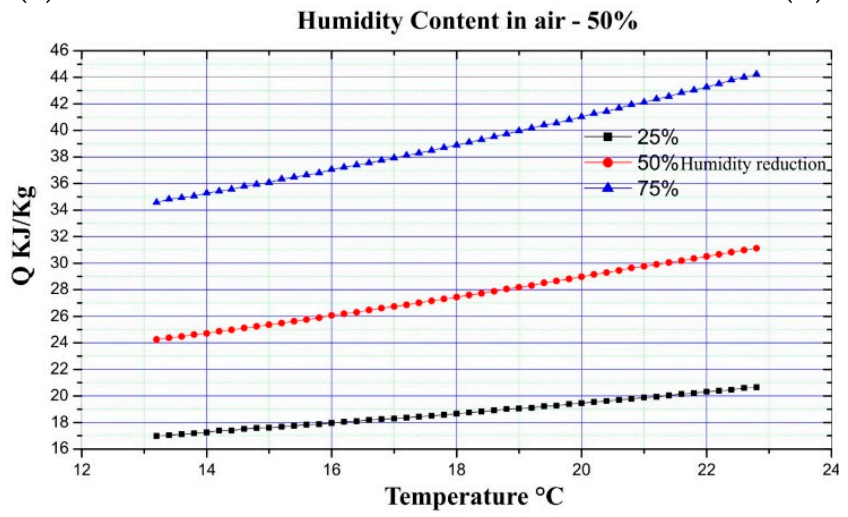

(c)

Figure 8. Heat to be removed for the three percent humidity reduction (25\%, 50\% and $75 \%$ ) with air humidity content of $50 \%(\mathbf{c}), 60 \%(\mathbf{b})$, and $70 \%$ (a).

Table 1 is very important for the purposes of this paper and for AWG dimensioning as it defines the range of heat that must be extracted from the air entering the system. With the above results, the maximum amount of heat to be extracted is $46.2541 \mathrm{KJ} / \mathrm{kg}$ and the minimum of $13.449 \mathrm{~kJ} / \mathrm{kg}$. To carry out a study that covers the maximum and minimum values, the graph lines whose value is the highest for each of the lines of $25 \%, 50 \%$ and $75 \%$ reduction were used, since by studying these lines the values below them will be covered. As mentioned above, once the amount of heat that must be extracted (Q) from the dehumidification process is known, any type or medium of possible energy can be used to carry out the heat transfer of that amount of heat. The possible energy sources that can be used directly in the processes can include geothermal energy or solar energy, or indirect means that produce electrical energy by means of wind energy or photovoltaic solar energy that provide the AWG with electrical energy for its operation. It is noteworthy that the Matehuala region has all these energy resources available for use.

Table 1. Maximum values, minimum heat required to extract with respect to relative humidity.

\begin{tabular}{cccc}
\hline & \multicolumn{3}{c}{ Humidity Reduction } \\
\cline { 2 - 4 } Humidity Content & $\mathbf{2 5 \%}$ & $\mathbf{5 0 \%}$ & $\mathbf{7 5 \%}$ \\
\cline { 2 - 4 } & & Heat $\mathbf{Q} \mathbf{~ ( k J / k g )}$ \\
& & $\mathbf{M a x} @ \mathbf{2 2 . 8 8}{ }^{\circ} \mathbf{C} / \mathbf{M i n} @ \mathbf{~} \mathbf{1 3 . 1 4}{ }^{\circ} \mathbf{C}$ \\
\hline $50 \%$ & $19 / 16.8$ & $31 / 24.5$ & $44 / 34.8$ \\
$60 \%$ & $21 / 17$ & $31 / 24.3$ & $44.3 / 34.5$ \\
$70 \%$ & $17.5 / 13.7$ & $30.15 / 22$ & $46.8 / 34$ \\
\hline
\end{tabular}




\subsection{Case Study Evaluation}

Based on the previous results, the case study for three types of refrigeration packages with the following capacities was carried out: 1 ton of refrigeration ( $3516.85 \mathrm{~J} / \mathrm{s}, 1141 \mathrm{~W}$ consumption), $\frac{1}{2}$ ton of refrigeration $\left(1758.42 \mathrm{~J} / \mathrm{s}, 570.5 \mathrm{~W}\right.$ consumption) and $\frac{1}{4}$ ton of refrigeration $(879.21 \mathrm{~J} / \mathrm{s}, 285.25 \mathrm{~W}$ consumption). The previous capacities were selected so that they could be used in common households predominant among the majority of the population. The compressor energy consumption could be used to dimension the photovoltaic energy source. The required power, the region's peak solar hours (PSH) and daily operating time of the compressors had to be known in order to dimension the solar panels. The Table 2 shows the power required and generated for the refrigeration package:

Table 2. Number of photovoltaic (PV) panels and power for each compressor.

\begin{tabular}{ccccc}
\hline Package & $\begin{array}{c}\text { Tons of } \\
\text { Refrigeration }\end{array}$ & $\begin{array}{c}\text { Power Required } \\
(\text { W) }\end{array}$ & Number of Panels & $\begin{array}{c}\text { Power Generated } \\
\text { by the Panel (W) }\end{array}$ \\
\hline 1 & 1 & 1141 & 1 & 1150 \\
2 & $1 / 2$ & 570.5 & 1 & 600 \\
3 & $1 / 4$ & 285.25 & 1 & 300 \\
\hline
\end{tabular}

The amount of watts generated by each panel during each month of the year could be calculated by multiplying the PSH for each month by the power of the panel, as shown in the Figure 9:

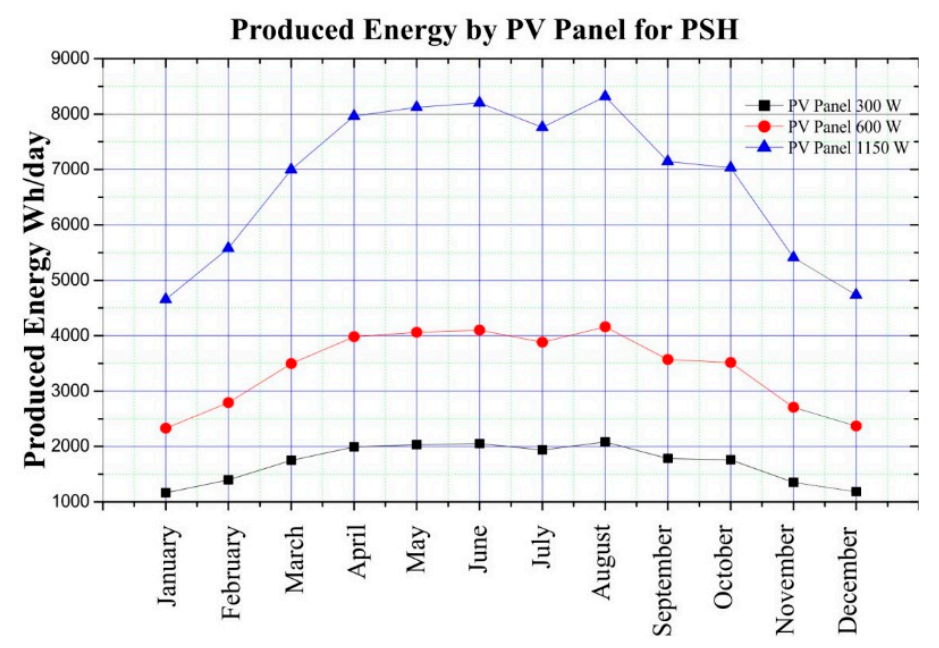

Figure 9. Produced energy by each photovoltaic panel for the peak solar hours (PSHs).

The following equation calculates the time that each refrigeration package would take to extract the heat $(Q)$ necessary to condense the air humidity for each kilogram of humid air:

$$
\text { Condensing time }=\frac{\text { Heat to be extracted, in J }}{\text { Tons of refrigeration, in } \frac{\mathrm{J}}{\mathrm{s}}}
$$

The following table shows the time it would take for the AWG to condense the moisture present in the air for the proposed refrigeration packages:

Table 3 attempts to estimate the time that the AWG would use to condense the moisture contained in the air, and thus relate the time to PSH, which is the system's working time. 
Table 3. Condensation times for each refrigeration package in seconds.

\begin{tabular}{cccccccccc}
\hline & \multicolumn{3}{c}{$\mathbf{1 / 4}$ Ton of Refrigeration } & \multicolumn{3}{c}{$\mathbf{1 / 2}$ Ton of Refrigeration } & \multicolumn{3}{c}{$\mathbf{1}$ Ton of Refrigeration } \\
\cline { 2 - 11 } & \multicolumn{3}{c}{ Reduction } & \multicolumn{3}{c}{ Reduction } & \multicolumn{3}{c}{ Reduction } \\
\cline { 2 - 12 } & $\mathbf{2 5 \%}$ & $\mathbf{5 0} \%$ & $\mathbf{7 5 \%}$ & $\mathbf{2 5 \%}$ & $\mathbf{5 0} \%$ & $\mathbf{7 5 \%}$ & $\mathbf{2 5 \%}$ & $\mathbf{5 0 \%}$ & $\mathbf{7 5 \%}$ \\
\hline Max & 19.32 & 27.58 & 38.72 & 9.66 & 13.79 & 19.36 & 4.83 & 6.89 & 9.68 \\
Min & 23.48 & 35.39 & 52.60 & 11.74 & 17.69 & 26.30 & 5.87 & 8.84 & 13.15 \\
\hline
\end{tabular}

\subsection{Water Harvesting}

The harvesting (condensation) of relative air humidity is the main factor in this research, and is calculated as follows:

$$
\mathrm{Kg}_{\text {water harvested }}=\frac{(\mathrm{PSH} * 3600)(\text { Humidity } * \% \text { reduction })}{\text { Time to condense }}
$$

The application of the above equation involves all the factors calculated above. The results of the water harvested for the case study are shown in the Tables 4-6.

The above tables show the behaviour of AWG water harvesting for each refrigeration package proposed and for the study region's conditions. The month with the least amount of water collection was January, with minimum quantities of 3.6 to $0.89 \mathrm{~L} /$ day, whereas August was the month with the highest amount of harvesting with a maximum of 18 to $3.9 \mathrm{~L} /$ day. The variations in the amount of water captured by the AWG were due to the daily hours of operation in each month of the year (equal to the PSH), the amount of moisture present in the air and the refrigeration packages used.

Table 4. Maximum and minimum amounts of water harvested in the months of the year with a compressor with 1 ton of refrigeration capacity.

\begin{tabular}{|c|c|c|c|c|c|c|}
\hline \multirow{3}{*}{ Month } & \multicolumn{6}{|c|}{ Water Harvested with 1 Ton of Refrigeration (Litres) } \\
\hline & \multicolumn{2}{|c|}{$25 \%$ Reduction } & \multicolumn{2}{|c|}{$50 \%$ Reduction } & \multicolumn{2}{|c|}{$75 \%$ Reduction } \\
\hline & Max & Min & Max & Min & Max & Min \\
\hline January & 5.4 & 3.56 & 7.17 & 4.99 & 10.1 & 7.49 \\
\hline February & 6.47 & 4.27 & 8.59 & 5.98 & 12.2 & 8.98 \\
\hline March & 8.11 & 5.35 & 10.77 & 7.50 & 15.30 & 11.26 \\
\hline April & 9.24 & 6.09 & 12.26 & 8.54 & 17.42 & 12.82 \\
\hline May & 9.43 & 6.22 & 12.51 & 8.71 & 17.77 & 13.08 \\
\hline June & 9.52 & 6.28 & 12.63 & 8.80 & 17.94 & 13.21 \\
\hline July & 9.00 & 5.94 & 11.95 & 8.32 & 16.97 & 12.49 \\
\hline August & 9.65 & 6.37 & 12.81 & 8.92 & 18.19 & 13.39 \\
\hline September & 8.29 & 5.47 & 11.00 & 7.66 & 15.62 & 11.50 \\
\hline October & 8.15 & 5.38 & 10.82 & 7.54 & 15.37 & 11.32 \\
\hline November & 6.27 & 4.14 & 8.33 & 5.80 & 11.83 & 8.71 \\
\hline December & 5.49 & 3.62 & 7.29 & 5.08 & 10.35 & 7.62 \\
\hline
\end{tabular}


Table 5. Maximum and minimum amounts of water harvested in the months of the year with a compressor with $\frac{1}{2}$ ton of refrigeration capacity.

\begin{tabular}{ccccccc}
\hline \multirow{2}{*}{ Month } & \multicolumn{5}{c}{ Water Harvested with $\mathbf{1 / 2}$ Ton of Refrigeration (Litres) } \\
\cline { 2 - 6 } & \multicolumn{2}{c}{$\mathbf{2 5 \%}$ Reduction } & \multicolumn{5}{c}{$\mathbf{5 0}$ \% Reduction } & 75\% Reduction \\
\cline { 2 - 6 } & Max & Min & Max & Min & Max & Min \\
\hline January & 2.7 & 1.78 & 3.58 & 2.49 & 5.09 & 3.74 \\
February & 3.23 & 2.13 & 4.29 & 2.99 & 6.10 & 4.49 \\
March & 4.05 & 2.67 & 5.38 & 3.75 & 7.65 & 5.63 \\
April & 4.62 & 3.04 & 6.13 & 4.27 & 8.71 & 6.41 \\
May & 4.71 & 3.11 & 6.25 & 4.35 & 8.88 & 6.54 \\
June & 4.76 & 3.14 & 6.31 & 4.40 & 8.97 & 6.60 \\
July & 4.50 & 2.97 & 5.97 & 4.16 & 8.48 & 6.24 \\
August & 4.82 & 3.18 & 6.40 & 4.46 & 9.09 & 6.69 \\
September & 4.14 & 2.73 & 5.50 & 3.83 & 7.81 & 5.75 \\
October & 4.07 & 2.69 & 5.41 & 3.77 & 7.68 & 5.66 \\
November & 3.13 & 2.07 & 4.16 & 2.90 & 5.91 & 4.35 \\
December & 2.74 & 1.81 & 3.64 & 2.54 & 5.17 & 3.81 \\
\hline
\end{tabular}

Table 6. Maximum and minimum amounts of water harvested in the month of the year with a compressor with $\frac{1}{4}$ ton of refrigeration capacity.

\begin{tabular}{ccccccc}
\hline \multirow{2}{*}{ Month } & \multicolumn{5}{c}{ Water Harvested with $\mathbf{1 / 4}$ Ton of Refrigeration (Litres) } \\
\cline { 2 - 6 } & \multicolumn{2}{c}{$\mathbf{2 5 \%}$ Reduction } & 50\% & Reduction & 75\% Reduction \\
\cline { 2 - 6 } & Max & Min & Max & Min & Max & Min \\
\hline January & 1.35 & 0.89 & 1.79 & 1.24 & 2.54 & 1.87 \\
February & 1.61 & 1.06 & 2.14 & 1.49 & 3.05 & 2.24 \\
March & 2.02 & 1.33 & 2.69 & 1.87 & 3.82 & 2.81 \\
April & 2.31 & 1.52 & 3.06 & 2.13 & 4.35 & 3.20 \\
May & 2.35 & 1.55 & 3.12 & 2.17 & 4.44 & 3.27 \\
June & 2.38 & 1.57 & 3.15 & 2.20 & 4.48 & 3.30 \\
July & 2.25 & 1.48 & 2.98 & 2.08 & 4.24 & 3.12 \\
August & 2.41 & 1.59 & 3.20 & 2.23 & 4.54 & 3.34 \\
September & 2.07 & 1.36 & 2.75 & 1.91 & 3.90 & 2.87 \\
October & 2.03 & 1.34 & 2.70 & 1.88 & 3.84 & 2.83 \\
November & 1.56 & 1.03 & 2.08 & 1.45 & 2.95 & 2.17 \\
December & 1.37 & 0.90 & 1.82 & 1.27 & 2.58 & 1.90 \\
\hline
\end{tabular}

\subsection{Cost per Litre of Water Produced}

It is possible to estimate the cost per litre or the cost of generating a litre of water with the maximum and minimum values of water harvested. As is well known, for the case studies photovoltaic panels were used as the AWG power source; in order to estimate the cost we will consider electrical power to have been supplied by the local power company, CFE, at the corresponding rate (1A). Rates for the Matehuala region have three levels: Basic (is the first $150 \mathrm{kWh}$ of usage, charged at a rate of 0.062 USD), intermediate (the following $150 \mathrm{kWh}$ of usage after the basic rate, charged at a rate of 0.077 USD) and surplus (any usage exceeding the intermediate rate, charged at a rate of 0.221 USD per $\mathrm{kWh}$ ).

To calculate the cost per litre of water produced by the AWG, the following equation was used:

$$
\mathrm{USD} / \text { litre }=\frac{(\text { Watts produced })(\$ \text { per KWh })}{\text { Litres of water produced }}
$$

For this analysis, the maximum and minimum amounts of water harvested during the months of the year (January and February) were taken into account and the cost of water production in the region was estimated using the different refrigeration packages. Results are shown in Figure 10. 


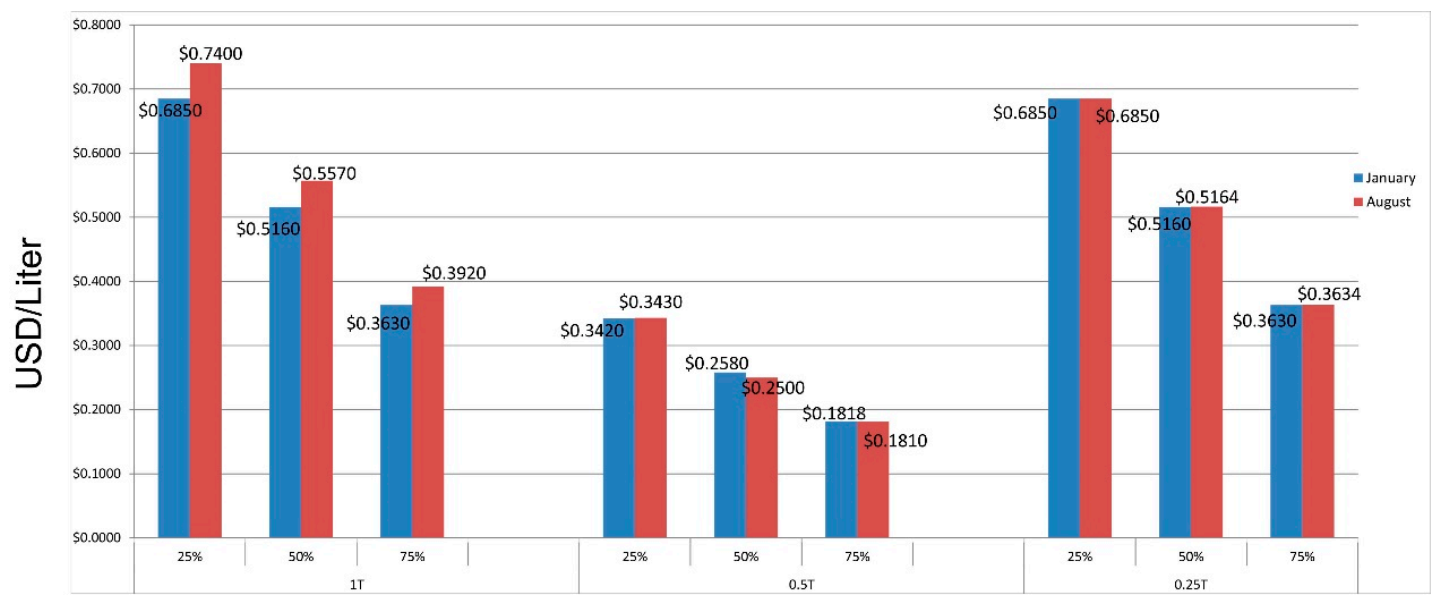

Figure 10. Cost per litre of water produced by the atmospheric water generator.

The results show that the cost per litre of water was very low, even when an average consumption was maintained (average rate), in a range of $\$ 0.0093$ and $\$ 0.038 \mathrm{USD} / \mathrm{L}$ of water harvested by the AWG. The costs obtained per litre harvested were affordable to any type of population that lacks water services.

\section{Discussion}

The use of AWGs as a solution to water scarcity has the advantages of simplicity of implementation and energy-free or renewable-energy operation. However, at the same time, there are also disadvantages in terms of seasonality, geographical location and climates [40]. The climatological study developed shows that the conditions of the Matehuala, SLP, region are favourable for the design and use of AWGs for the harvesting of atmospheric air water. The literature notes that favourable conditions for AWG use are above $40 \% \mathrm{RH}$ ( $\geq 40 \%$ ) [42]. With an average annual humidity of approximately $60 \%$ despite being a semi-arid region, the humidity levels are suitable for the application proposed in this work. To evaluate the profitability and functionality of the AWG, a new moisture harvest index (MHI) presented in [52] was introduced, which relates the latent heat of condensation to the total heat transfer in the dehumidifier. This index establishes that the economic, energy and operational conditions are unfavourable for the use of AWGs in conditions or regions that have an $\mathrm{MHI}<0.3$. For the region studied from the psychrometric chart, the values of the MHI can vary in the proposed range of temperatures and humidity of approximately 0.3 to 0.45 , the former being the worst case and the latter the best case that can prevail in the region. However, air quality is one of the parameters that is most questioned in the use of AWGs because it is related to the quality of the water collected. There is little literature devoted to the study of inhalation as a route of exposure to arsenic, whereas most consider that the main exposure is based on oral exposure through drinking water or as indicated by CSTEE (2001), through food. However, CSTEE (2001) states that, although air is not a major route of exposure in quantitative terms, the presence of arsenic in the environment is due to the following: Air $<1 \%$, cigarette smoke $0-16 \%$, fresh water $0-33 \%$ and food $50-98 \%$ [53]. Human exposure to arsenic through air generally occurs at very low concentrations ranging from 0.4 to $30 \mathrm{ng} / \mathrm{m}^{3}$. The United States Environmental Protection Agency has estimated that approximately 40 to $90 \mathrm{ng}$ of arsenic per day are inhaled by humans. In non-contaminated areas, approximately $50 \mathrm{ng}$ or less of arsenic per day are inhaled [54,55]. A very recurrent discussion in scientific forums is whether arsenic or contaminants in the air affect the quality of water collected by the AWG or by collecting rainwater. There are no exact data on arsenic levels in the air in the study region, but results found in scientific review show that the levels should be acceptable, without greatly affecting the quality of water harvested from the atmospheric air. It has been reported that the water harvested from the atmospheric air [56-58] presents important quantities of faecal, while parameters such as $\mathrm{pH}$, hardness, dissolved solids, 
and conductivity, heavy metals, alkalinity, odour, flavour, nitrites and nitrates are within the limits established by national standards for drinking water. Few studies report the presence of arsenic in harvested water; the arsenic indexes reported are less than $0.007 \mathrm{mg} / \mathrm{L}$, thus remaining within the standard of water for human consumption [59]. In Mexico, rainwater has been harvested [27] in which very low levels of fluoride and arsenic have been measured in the water collected. A maximum concentration of $0.004 \mathrm{mg} / \mathrm{L}$ was found, well below NOM-127-SSA1-1994 [60] (0.025 mg/L) and WHO guidelines [61] $(0.010 \mathrm{mg} / \mathrm{L})$. The water harvesting procedure does not contemplate water coming into contact with soil. In contrast in [47] they report arsenic levels of $0.2 \mathrm{mg} / \mathrm{L}$ in the water collected from rain that entered into contact with soil. In general, it is reported that water captured from the environment has excellent conditions for human use as long as it goes through a process of microbiological quality improvement [62]. Feasibility not only contemplates the availability of environmental resources for the design and use of AWG, but also considers the cost of producing freshwater. In our study, we obtained costs in the range of 0.0093 and $\$ 0.038 \mathrm{USD} / \mathrm{L}$. These costs are affordable to the population compared to the investment or costs of other water supply technologies. For example, in [33] costs ranging from 0.2 to $0.27 \mathrm{USD} / \mathrm{L}$ using different types of salts and solar energy have been reported, while Deniz et al. [63] reported a cost of $0.0981 \mathrm{USD} / \mathrm{L}$ with a solar distillation system. Tariq et al. [47] reported a cost of $0.030 \mathrm{USD} / \mathrm{L}$ using a desalination humidifier-dehumidifier system. The costs that we obtained in the production of fresh water are competitive and even lower than those reported in the literature.

\section{Conclusions}

In this work, a feasibility analysis was conducted on the use of atmospheric water generators (AWGs) as a possible solution to water pollution and scarcity in the Matehuala, SLP, Mexico region, which has a lot of mining activity. It was found that the main sources of As exposure in the region are food, soil and water, especially in the hydraulic network system that supplies the region's population. Much of the local and rural population suffers water shortages. The following conclusions are obtained from the analysis carried out in our work:

- Population growth in the region is inevitable, and the demand for fresh water will increasingly be a matter of government priority. Current figures show that despite the growth of the population and the demand for water, the volumetric production has remained relatively constant for 10 years. In 2000, there were 64,206 inhabitants with a volumetric water production that could supply 6 , $274,629 \mathrm{~m}^{3}$. By 2017 , there were over 99,015 inhabitants, while volumetric water production was $6,641,262 \mathrm{~m}^{3}$. In 2000, there were 18,159 water intakes compared to 28,576 in 2018. This will gradually lead to the search for new technologies to provide water.

- The region of Matehuala, SLP, Mexico has the necessary environmental conditions for the use of AWGs for the harvesting of atmospheric air water, with an average relative humidity of approximately $60 \%$. This value is adequate from the point of view of functionality, economy and viability. In addition to the above, solar (annual average of $5.5 \mathrm{PSH}$ and $720 \mathrm{~W} / \mathrm{m}^{2}$ max) and wind (average annual speeds of $2.2 \mathrm{~m} / \mathrm{s}$ to $4.1 \mathrm{~m} / \mathrm{s}$ ) energy sources are viable.

- Using the mathematical model developed in this work and evaluated with the climatic conditions of the region, monthly water harvesting was determined. January had the lowest harvest, with minimum quantities of 3.6 to $0.89 \mathrm{~L} /$ day, whereas August had the greatest harvest, with maximum amounts of 18 to $3.9 \mathrm{~L} /$ day.

- Water production costs were obtained in the range of \$ 0.0093 and \$ 0.038 USD per litre of water captured by the AWG, showing that the costs obtained per litre harvested are affordable to any type of population that lacks water services.

In general, the region of Matehuala, SLP, Mexico was found to be a feasible area for the use of atmospheric water generators (AWGs) for capturing water from atmospheric air. The implementation of AWGs will help the preservation of ecosystems and the environment in general, benefiting people or communities with limited water supply. 
Author Contributions: J.A.M.-E., F.J.H.-R. and P.C.-A. developed the idea and conceptualization of the study; P.C.-A. and J.M.-M. conceived and wrote the paper together; M.Z.S.-L.; R.A.F.-D. and carried out the methodology; F.J.M.-L. and C.M.V.-C. contributed materials and analysis tools. All the co-authors contributed to the discussion of the results and preparation of the manuscript.

Funding: This research received no external funding.

Acknowledgments: We thank the General Coordination of the National Meteorological Service (CGSMN) of the National Water Commission (CONAGUA) for providing us with the historical data of the climate in the region of Matehuala, SLP, records from the network of automatic weather stations (EMAs).

Conflicts of Interest: The authors declare no conflict of interest.

\section{References}

1. Claire, S. The Last Drop. Mazaya Summer Issue 2002, 22-25.

2. Eslami, M.; Tajeddini, F.; Etaati, N. Thermal analysis and optimization of a system for water harvesting from humid air using thermoelectric coolers. Energy Convers. Manag. 2018, 174, 417-429. [CrossRef]

3. Xiao, G.; Wang, X.; Ni, M.; Wang, F.; Zhu, W.; Luo, Z.; Cen, K. A review on solar stills for brine desalination. Appl. Energy 2013, 103, 42-52. [CrossRef]

4. Mekonnen, M.M.; Hoekstra, A.Y. Four billion people facing severe water scarcity. Sci. Adv. 2016, 2, e1500323. [CrossRef] [PubMed]

5. Smedley, P.L.; Kinniburgh, D.G. A review of the source, behavior and distribution of arsenic in natural waters. Appl. Geochem. 2002, 17, 517-568. [CrossRef]

6. Ravenscroft, P.; Brammer, H.; Richards, K. Arsenic Pollution: A Global Synthesis, 1st ed.; John Wiley \& Sons: Singapore, 2009; Volume 28.

7. INEGI. Prontuario de Información Geográfica Municipal de los Estados Unidos Mexicanos. Matehuala, San Luis Potosí; Instituto Nacional de Estadística Geografía e Informática: Aguascalientes, Mexico, 2010.

8. Manas, R.F. Arsenic Profile. 2000. American Metal Market Web Site. Available online: http://www.amm. com/ref/arsen.htm/ (accessed on 1 June 2017).

9. Yáñez, L.; García-Nieto, E.; Roas, E.; Carrizales, L.; Mejía, J.; Calderón, J.; Razo, I.; Díaz-Barriga, F. DNA damage in blood cells from children exposed to arsenic and lead in a mining area. Environ. Res. 2003, 93, 231-240. [CrossRef] [PubMed]

10. WHO. Arsénico. Available online: http://www.who.int/mediacentre/factsheets/fs372/es/ (accessed on 1 December 2017).

11. WHO. Arsenic and Arsenic Compounds (Environmental Health criteria 224), 2nd ed.; World Health Organizationm international programme on Chemical Safety: Geneva, Switzerland, 2001.

12. ATSDR. Public Health Statement: Arsenic. Available online: http://www.atsdr.cdc.gov/phs/phs.asp?id=18\& tid=3 (accessed on 21 January 2017).

13. Alarcón-Herrera, M.T.; Bundschuh, J.; Nath, B.; Nicolli, H.B.; Gutierrez, M.; Reyes-Gomez, V.M.; Nuñez, D.; Martín-Dominguez, I.R.; Sracek, O. Co-occurrence of arsenic and fluoride in groundwater of semi-arid regions in Latin America: Genesis, mobility and remediation. J. Hazard. Mater. 2013, 262, 960-969. [CrossRef] [PubMed]

14. Mejía, J.J.; Carrizales, L.; Díaz-Barriga, F.; Metodología de identificación y evaluación de riesgo para la salud en sitios contaminados: Inspección de sitios peligrosos. Zona Minera de Villa de la Paz-Matehuala. Agencia Alem. Coop. Téc. 1999. Available online: http://www.bvsde.paho.org/eswww/fulltext/gtz/metoiden/metane03.html (accessed on 15 September 2017).

15. DOF. Norma Oficial Mexicana NOM-147-SEMARNAT/SSA1-2004-Establece Criterios Para la Caracterización y Determinación de Concentraciones de Remediación de Suelos Contaminados Por Arsénico, Bario, Berilio, Cadmio, Cromo Hexavalente, Mercurio, Níquel, Plata, Plomo, Selenio, Talio, Vanadio; SEMARNAT/SSA1; DOF: Mexico City, Mexico, 2007; p. 69.

16. Ruíz-Huerta, E.A.; de la Garza Varela, A.; Gómez-Bernal, J.M.; Castillo, F.; Avalos-Borja, M.; SenGupta, B.; Martínez-Villegas, N. Arsenic contamination in irrigation water, agricultural soil and maize crop from an abandoned smelter site in Matehuala, Mexico. J. Hazard. Mater. 2017, 330-339. [CrossRef] [PubMed]

17. Martínez-Villegas, N.; Hernández, A.; Meza-Figueroa, D.; Sen-Gupta, B. Distribution of Arsenic and Risk Assessment of Activities on Soccer Pitches Irrigated with Arsenic-Contaminated Water. Int. J. Environ. Res. Public Health 2018, 156, 1060. [CrossRef] [PubMed] 
18. Briones-Gallardo, R.; Razo-Soto, I. Contaminación de aguas naturales por arsénico asociado a la actividad minero-metalúrgica: Caso de estudio en san Luis Potosí, México. Memoria en Extenso. In Proceedings of the Congreso Internacional en Gestión Sostenible del Agua: Reutilización, Tratamiento y Evaluación de la Calidad, Medellín, Colombia, 16-18 July 2008. (In Spanish).

19. Bueno-Pedroza, A. Interpretación Hidrogeoquímica de los Sistemas de Flujo de la Parte Norte del Altiplano Potosino. Master's Thesis, Universidad Autónoma de Nuevo León, San Nicolás de los Garza, Mexico, 2005. (In Spanish).

20. Servicios de agua potable y saneamiento de Matehuala (Sapsam). Informe Técnico 2010-2018 Fuentes Alternas de Abastecimiento de Agua para la Cuidad de Matehuala; Servicios de agua potable y saneamiento de Matehuala (Sapsam): Matehuala, Mexico, 2019. (In Spanish)

21. Kim, N.K.; Kang, D.H.; Eom, H.; Kang, H.W. Biomimetic fog harvesting surface by photo-induced micro-patterning of zinc-oxide silver hierarchical nanostructures. Appl. Surf. Sci. 2019, 470, 161-167. [CrossRef]

22. Hamed, A.; Aly, A.; Zeidan, E. Application of solar energy for recovery of water from atmospheric air in climatic zones of Saudi Arabia. Nat. Resour. 2011, 2, 8-17. [CrossRef]

23. Mahkamov, K.; Akhatov, J.S. Experimental study of the performance of multieffect solar thermal water desalination system. Appl. Sol. Energy 2008, 44, 31-34. [CrossRef]

24. Parekh, S.; Farid, M.M.; Selman, J.R.; Al-Hallaj, S. Solar desalination with a humidification-dehumidification technique-A comprehensive technical review. Desalination 2004, 160, 167-186. [CrossRef]

25. Calzadilla, A.; Rehdanz, K.; Tol, R. Water scarcity and the impact of improved irrigation management: A computable general equilibrium analysis. Agric. Econ. 2011, 42, 305-323. [CrossRef]

26. Saettone, E. Desalination using a parabolic-trough concentrator. Appl. Sol. Energy 2012, 48, $254-259$. [CrossRef]

27. Gispert, M.I.; Hernández, M.A.A.; Climent, E.L.; Flores, M.F.T. Rainwater Harvesting as a Drinking Water Option for Mexico City. Sustainability 2018, 10, 3890. [CrossRef]

28. Valdes Ramos, A.; Aguilera Gonzalez, E.N.; Tobón Echeverri, G.; Samaniego Moreno, L.; Díaz Jiménez, L.; Carlos Hernández, S. Potential Uses of Treated Municipal Wastewater in a Semiarid Region of Mexico. Sustainability 2019, 11, 2217. [CrossRef]

29. Zhang, Y.; Ravi, S.K.; Tan, S.C. Systematic Study of the Effects of System Geometry and Ambient Conditions on Solar Steam Generation for Evaporation Optimization. Adv. Sustain. Syst. 2019, 1900044. [CrossRef]

30. Gandhidasan, P.; Abualhamayel, H.I. Modeling and testing of a dew collection system. Desalination 2005, 180, 47-51. [CrossRef]

31. Beysens, D. The formation of dew. Atmos. Res. 1995, 39, 215-237. [CrossRef]

32. Odeh, I.; Arar, S.; Al-Hunaiti, A.; Sa'aydeh, H.; Hammad, G.; Duplissy, J.; Vuollekoski, H.; Korpela, A.; Petäjä, T.; Kulmala, M.; et al. Chemical investigation and quality of urban dew collections with dust precipitates. Environ. Sci. Pollut. Res. 2017, 24, 12312-12318. [CrossRef] [PubMed]

33. Srivastava, S.; Yadav, A. Economic analysis of water production from atmospheric air using Scheffler reflector. Appl. Water Sci. 2019, 9. [CrossRef]

34. Mohamed, M.H.; William, G.E.; Fatouh, M. Solar energy utilization in water production from humid air. Sol. Energy 2017, 148, 98-109. [CrossRef]

35. Abd Manaf, I.; Durrani, F.; Eftekhari, M. A review of desiccant evaporative cooling systems in hot and humid climates. Adv. Build. Energy Res. 2018. [CrossRef]

36. Kallenberger, P.A.; Fröba, M. Water harvesting from air with a hygroscopic salt in a hydrogel-derived matrix. Commun. Chem. 2018, 1, 28. [CrossRef]

37. Liang, H.; Abshaev, M.T.; Abshaev, A.M.; Huchunaev, B.M.; Griffiths, S.; Zou, L. Water vapor harvesting nanostructures through bioinspired gradient-driven mechanism. Chem. Phys. Lett. 2019, 728, 167-173. [CrossRef]

38. Nandakumar, D.K.; Zhang, Y.; Ravi, S.K.; Guo, N.; Zhang, C.; Tan, S.C. Solar Energy Triggered Clean Water Harvesting from Humid Air Existing above Sea Surface Enabled by a Hydrogel with Ultrahigh Hygroscopicity. Adv. Mater. 2019, 31, 1806730. [CrossRef] [PubMed]

39. Zhao, D.; Aili, A.; Zhai, Y.; Xu, S.; Tan, G.; Yin, X.; Yang, R. Radiative sky cooling: Fundamental principles, materials, and applications. Appl. Phys. Rev. 2019, 6. [CrossRef]

40. Arias, J.E.; Flores, J.J. Winter Dew Harvest in Mexico City. Atmosphere 2016, 7, 2. [CrossRef] 
41. Alahmer, A.; Al-Dabbas, M.; Alsaqoor, S.; Al-Sarayreh, A. Utilizing of Solar Energy for Extracting Freshwater from Atmospheric Air. Appl. Sol. Energy 2018, 54, 110-118. [CrossRef]

42. Kim, H.; Rao, S.R.; Kapustin, E.A.; Zhao, L.G.; Yang, S.; Cordova, K.E.; Wang, E.N. Adsorption-based atmospheric water harvesting device for arid climates. Nat. Commun. 2018, 9, 1191. [CrossRef] [PubMed]

43. Kobayashi, M. A method of obtaining water in arid land. Sol. Energy 1963, 7, 93-99. [CrossRef]

44. Bagheri, F. Performance investigation of atmospheric water harvesting systems. Water Resour. Ind. 2018, 20, 23-28. [CrossRef]

45. Rey, M.; Lauro, F. Ocean thermal energy and desalination. Desalination 1981, 39, 159-168. [CrossRef]

46. Gutiérrez, J.; Porta-Gándara, M.A.; Fernández, J.L. Distilled water production using geothermally heated seawater. Desalination 2009, 249, 41-48. [CrossRef]

47. Tariq, R.; Sheikh, N.A.; Xamán, J.; Bassam, A. An innovative air saturator for humidification-dehumidification desalination application. Appl. Energy 2018, 228, 789-807. [CrossRef]

48. El-Ghonemy, A.M.K. Performance test of a sea water multi-stage flash distillation plant: Case study. Alex. Eng. J 2401, 57, 2401-2413. [CrossRef]

49. Chaitanya, B.; Bahadur, V.; Thakur, A.D.; Raj, R. Biomass-gasification-based atmospheric water harvesting in India. Energy 2018, 165, 610-621. [CrossRef]

50. Ozkan, O.; Wikramanayake, E.D.; Bahadur, V. Modelling humid air condensation in waste natural gas-powered atmospheric water harvesting systems. Appl. Eng. 2017, 118, 224-232. [CrossRef]

51. Wikramanayake, E.D.; Ozkan, O.; Bahadur, V. Landfill gas-powered atmospheric water harvesting for oilfield operations in the United States. Energy 2017, 138, 647-658. [CrossRef]

52. Gido, B.; Friedler, E.; David, M.; Broday, D.M. Assessment of atmospheric moisture harvesting by direct cooling. Atmos. Res. 2016, 182, 156-162. [CrossRef]

53. European Scientific Committee on Toxicity, Ecotoxicity and Environment (CSTEE). Ambient Air Pollution by Arsenic Compounds-Final Version; CSTEE: Brussels, Belgium, 2000.

54. Environmental Protection Agency. Inorganic Arsenic: Toxicity and Exposure Assessment for Children's Health. Available online: http://www.epa.gov/teach/chem_summ/Arsenic_summary.pdf (accessed on 10 December 2016).

55. Chung, J.Y.; Yu, S.D.; Hong, Y.S. Environmental source of arsenic exposure. J. Prev. Med. Public Health 2014, 47, 253-257. [CrossRef] [PubMed]

56. Bautista-Olivas, A.L.; Tovar-Salinas, J.L.; Mancilla-Villa, O.R.; Flores-Magdaleno, H.; Ramírez-Ayala, C.; Arteaga-Ramírez, R.; Vázquez-Peña, M. Concentración de metales traza en el agua condensada de la humedad atmosférica en el valle de México. Interciencia 2014, 39, 234-240.

57. Al-hassan, G.A. Fog Water Collection Evaluation in Asir Region-Saudi Arabia. Water Resour. Manag. 2009, 23, 2805-2813. [CrossRef]

58. Shanyengana, E.S.; Henschel, J.R.; Seely, M.K.; Sanderson, R.D. Exploring fog as a supplementary water source in Namibia. Atmos. Res. 2002, 64, 251-259. [CrossRef]

59. Abualhamayel, H.I.; Gandhidasan, P. Design and testing of large fog collectors for water harvesting in Asir region, Kinddom of Saudi Arabia. In Proceedings of the 5th International Conference on Fog, Fog Collection and Dew, Munster, Germany, 25-30 July 2010.

60. Secretaría de Salud Modificación a la Norma Oficial Mexicana NOM-127-SSA1-1994 (2000). Salud Ambiental. Agua Para uso y Consumo Humano. Límites Permisibles de Calidad y Tratamientos a que se Debe Someter el Agua Para su Potabilización. Available online: http://www.salud.gob.mx/unidades/cdi/nom/m127ssa14.html (accessed on 1 March 2017). (In Spanish).

61. WHO (World Health Organization). Guidelines for Drinking-Water Quality. Available online: http: //apps.who.int/iris/bitstream/10665/44584/1/9789241548151_eng.pdf (accessed on 8 may 2017).

62. Jahne, M.; Pfaller, S.; King, D.; Garland, J.; Impellitteri, C. Evaluation of Atmospheric Water Generation Technology: Microbial Water Quality; U.S. Environmental Protection Agency: Washington, DC, USA, 2018.

63. Deniz, E.; Çınar, S. Energy, exergy, economic and environmental (4E) analysis of a solar desalination system with humidification-dehumidification. Energy Convers. Manag. 2016, 126, 12-19. [CrossRef]

(C) 2019 by the authors. Licensee MDPI, Basel, Switzerland. This article is an open access article distributed under the terms and conditions of the Creative Commons Attribution (CC BY) license (http://creativecommons.org/licenses/by/4.0/). 